\title{
8. NEOGENE BENTHIC FORAMINIFERAL BIOFACIES OF THE NEW JERSEY TRANSECT ${ }^{1}$
}

\author{
Miriam E. Katz and Kenneth G. Miller, Lamont-Doherty Geological Observatory of Columbia University ${ }^{2}$
}

\begin{abstract}
Quantitative study of benthic foraminifers from the upper Miocene to lower Pliocene section at Site 612 (1404 m present water depth) and the Pliocene section at Site 613 (2323 m present water depth) shows no evidence of widespread downslope transport of shallow-water biofacies or reworking of older material in the greater than $150 \mu \mathrm{m}$ size fraction. In contrast, upper Miocene sediments from Site 604 (2364 m present water depth) show extensive reworking and downslope transport. At Site 612, benthic foraminifers show a succession from an upper Miocene Bolivina alata-Nonionella sp. biofacies, to an uppermost Miocene Bulimina alazanensis biofacies, to a lower Pliocene Cassidulina reflexa biofacies, to an upper Pliocene Melonis barleeanum-Islandiella laevigata biofacies. Evidence suggests that the Pliocene biofacies are in situ, although they could have been transported downslope from the upper-middle bathyal zone. At Site 613, Uvigerina peregrina dominated the "middle" Pliocene, while Globocassidulina subglobosa was dominant in the early and late Pliocene. High abundances of U. peregrina at Site 613 are associated with high values of sedimentary organic carbon.
\end{abstract}

\section{INTRODUCTION}

On DSDP Leg 95, we drilled two sites on the passive U.S. continental margin off New Jersey: the lower continental slope Site 612 (1404 m present water depth; $38^{\circ} 49.21^{\prime} \mathrm{N}, 72^{\circ} 46.43^{\prime} \mathrm{W}$ ) and the upper continental rise Site $613\left(2323 \mathrm{~m}\right.$ present water depth; $38^{\circ} 46.26^{\prime} \mathrm{N}$, $72^{\circ} 30.43^{\prime} \mathrm{W}$ ). These sites, together with Sites 604 and 605 on the upper rise (van Hinte, Wise et al., in press), recovered thick Eocene and upper Miocene-Holocene sections. These sections are punctuated by numerous unconformities as a result of downslope erosion (Miller et al., 1985; Poag, 1985; Poag and Mountain, this volume; Poag and Low, this volume).

The Neogene record of benthic biofacies distribution on the New Jersey slope and upper rise is poorly known because of lack of material recovered prior to Legs 93 and 95. Paleoenvironmental interpretations of continental slope and rise biofacies may be complicated by downslope movement of shallow- and deep-water components. Despite the importance of downslope processes in continental margin erosion and transport (e.g., Natland, 1963; Stanley and Unrug, 1972; May et al., 1983), Holocene continental slope to upper rise benthic foraminifers ( $>150$ $\mu \mathrm{m}$ size fraction) from the northeastern U.S. margin show regionally consistent biofacies distribution with little evidence for downslope contamination (Miller and Lohmann, 1982; Streeter and Lavery, 1982). These authors noted that a Recent Uvigerina peregrina biofacies dominates the margin between about 900 and $2500 \mathrm{~m}$, associated with carbon and silt maxima in the slope and upper rise sediments. During the glacial Pleistocene, this $U$.

\footnotetext{
${ }^{1}$ Poag, C. W., Watts, A. B., et al., Init. Repts, DSDP, 95: Washington (U.S. Govt. Printing Office).

2 Address: (Katz, Miller) Lamont-Doherty Geological Observatory of Columbia University, Palisades, NY 10964
}

peregrina biofacies became established in abyssal depths $(>3000 \mathrm{~m})$ in the North Atlantic (Streeter and Shackleton, 1979; Ledbetter and Balsam, 1985), indicating a dramatic difference in the abyssal benthic environment between glacial and interglacial periods.

We have found little evidence for displaced benthic foraminifers both in the Holocene (Miller and Lohmann, 1982) and in the Eocene (Miller and Katz, this volume) on the margin off New Jersey. Eocene faunal patterns at Sites 612 and 613 are consistent with those observed at other deep-water DSDP sites. In contrast, the Pleistocene sections at Sites 612 and 613 show evidence of reworking of older material and downslope contamination by shallower material (Site 612 and 613 chapters; Poag and Low, this volume; Scott, this volume) and possible downslope transport of a Pleistocene Elphidium-dominated fauna (Site 612 and 613 chapters; Scott, this volume). We quantitatively examined benthic foraminifers from the upper Miocene to Pliocene sections at Sites 612 and 613 in order to evaluate distributional trends and to determine the extent of reworking and displacement of faunas. Pleistocene benthic foraminifers from these sites are discussed by Scott (this volume) and Poag and Low (this volume). Neogene biostratigraphic control is coarse at Sites 612 and 613 as a result of the scarcity of marker taxa (Site 612 and 613 chapters). Despite complications due to limited stratigraphic control and some reworking, we document general biofacies distributions during the late Miocene to Pliocene.

\section{METHODS}

Benthic foraminifers were studied quantitatively from samples taken from the upper Miocene-Pliocene sections recovered at Site 612 (12 samples; Table 1) and the Pliocene section at Site 613 (6 samples; Table 2). Additional core catcher samples were examined qualitatively for stratigraphic ranges. Twelve additional samples from Site 613 were examined quantitatively for Uvigerina abundances (Table 3). Six samples (supplied by S. W. Wise) from the upper Miocene section at Site 604 (2364 m present water depth) were qualitatively examined for evi- 
Table 1. Benthic foraminiferal census data, Site 612 .

\begin{tabular}{|c|c|c|c|c|c|c|c|c|c|c|c|c|}
\hline $\begin{array}{l}\text { Core-Section } \\
\text { (interval in } \mathrm{cm} \text { ) } \\
\text { Sub-bottom depth (m) } \\
\text { Number counted }\end{array}$ & $\begin{array}{c}7-2 \\
60-64 \\
46.7 \\
244\end{array}$ & $\begin{array}{l}50.3 \\
292\end{array}$ & $\begin{array}{l}56.6 \\
246\end{array}$ & $\begin{array}{l}11-2 \\
60-64 \\
80.5 \\
188\end{array}$ & $\begin{array}{l}11, \mathrm{CC} \\
84.0 \\
172\end{array}$ & $\begin{array}{l}12-2 \\
60-64 \\
90.2 \\
149\end{array}$ & $\begin{array}{l}12-5 \\
7-9 \\
94.2 \\
115\end{array}$ & $\begin{array}{l}107.1 \\
327\end{array}$ & $\begin{array}{l}14-2 \\
60-64 \\
109.6 \\
252\end{array}$ & $\begin{array}{l}116.8 \\
198\end{array}$ & $\begin{array}{c}15-2 \\
60-64 \\
119.3 \\
72\end{array}$ & $\begin{array}{c}16-5 \\
60-64 \\
133.3 \\
131\end{array}$ \\
\hline Sigmoilopsis schlumbergeri & 0.0 & 0.0 & 0.0 & 0.0 & 0.0 & 3.4 & 0.0 & 0.0 & 0.0 & 0.5 & 0.0 & 0.0 \\
\hline Vulvulina spinosa & 0.0 & 0.0 & 0.0 & 12.8 & 0.6 & 0.0 & 0.0 & 0.3 & 0.0 & 0.0 & 0.0 & 0.8 \\
\hline Martinotiella sp. & 0.0 & 0.0 & 0.0 & 0.5 & 0.0 & 0.0 & 0.0 & 1.5 & 2.0 & 5.1 & 11.1 & 14.5 \\
\hline Dentalina spp. & 0.4 & 1.0 & 0.4 & 0.0 & 0.0 & 0.0 & 0.0 & 0.3 & 0.4 & 0.0 & 0.0 & 0.0 \\
\hline Fursenkoina mexicana & 0.0 & 0.0 & 2.4 & 0.0 & 0.0 & 0.0 & 0.0 & 2.4 & 1.2 & 2.5 & 0.0 & 0.0 \\
\hline Chilostomellina sp. & 0.0 & 0.0 & 0.0 & 0.0 & 0.0 & 0.0 & 0.0 & 4.3 & 0.0 & 0.0 & 0.0 & 0.0 \\
\hline Karreriella subglabra & 0.0 & 0.0 & 0.0 & 0.0 & 0.0 & 0.0 & 0.0 & 0.3 & 0.0 & 1.0 & 2.8 & 0.0 \\
\hline Eggerella bradyi & 0.0 & 0.0 & 0.0 & 3.7 & 3.5 & 4.7 & 1.7 & 0.6 & 0.0 & 0.0 & 0.0 & 0.0 \\
\hline Stilostomella aculeata & 0.0 & 0.0 & 0.0 & 0.0 & 0.0 & 0.0 & 3.5 & 0.0 & 0.0 & 0.0 & 0.0 & 0.0 \\
\hline S. curvatura & 0.0 & 0.0 & 0.0 & 0.0 & 0.0 & 0.0 & 0.9 & 0.0 & 0.0 & 1.0 & 2.8 & 0.0 \\
\hline S. lepidula & 0.0 & 6.5 & 0.8 & 0.0 & 0.0 & 0.7 & 0.0 & 2.4 & 4.0 & 12.6 & 0.0 & 0.0 \\
\hline Bolivina alata & 0.0 & 0.7 & 7.3 & 0.0 & 0.0 & 0.0 & 0.0 & 11.0 & 29.4 & 16.7 & 1.4 & 0.0 \\
\hline Plectofrondicularia sp. & 5.3 & 5.5 & 1.2 & 1.1 & 0.6 & 0.0 & 0.0 & 2.8 & 5.2 & 19.2 & 2.8 & 0.0 \\
\hline Trifarina sp. & 0.0 & 0.3 & 0.4 & 0.0 & 0.0 & 0.0 & 0.0 & 0.0 & 0.0 & 0.0 & 0.0 & 3.8 \\
\hline Uvigerina probiscidea & 0.8 & 0.7 & 1.2 & 0.0 & 2.9 & 4.0 & 3.5 & 0.9 & 0.0 & 0.0 & 0.0 & 0.8 \\
\hline U. hispida & 0.0 & 0.0 & 0.0 & 0.0 & 0.0 & 0.0 & 0.9 & 0.0 & 0.0 & 0.0 & 18.1 & 0.0 \\
\hline$U$. peregrina & 0.4 & 1.0 & 0.0 & 0.5 & 0.0 & 1.3 & 0.9 & 0.0 & 0.0 & 0.0 & 0.0 & 0.0 \\
\hline$U$. mediterranea & 0.8 & 0.0 & 0.0 & 0.5 & 0.6 & 2.0 & 0.0 & 1.8 & 3.6 & 0.0 & 0.0 & 0.0 \\
\hline U. gallowayi & 0.0 & 0.0 & 0.0 & 0.0 & 20.9 & 0.0 & 0.0 & 0.0 & 0.0 & 0.0 & 0.0 & 0.0 \\
\hline Bulimina striata mexicana & 0.0 & 0.0 & 0.0 & 7.4 & 0.0 & 0.0 & 13.0 & 0.3 & 0.0 & 0.0 & 0.0 & 0.0 \\
\hline B. marginata & 0.0 & 0.0 & 0.0 & 0.0 & 9.3 & 0.0 & 0.0 & 0.0 & 0.0 & 0.0 & 0.0 & 0.0 \\
\hline B. aculeata & 6.1 & 1.4 & 10.2 & 0.0 & 0.0 & 0.0 & 0.0 & 0.0 & 0.0 & 0.0 & 0.0 & 0.0 \\
\hline B. gibba & 2.0 & 0.3 & 0.0 & 0.0 & 0.0 & 0.0 & 0.0 & 1.5 & 0.4 & 0.0 & 0.0 & 0.8 \\
\hline B. alazanensis & 0.0 & 0.0 & 0.0 & 0.5 & 0.0 & 0.7 & 62.6 & 13.5 & 2.0 & 2.0 & 0.0 & 0.0 \\
\hline Buliminella elongata & 0.0 & 0.0 & 0.0 & 0.0 & 0.0 & 0.0 & 0.0 & 0.0 & 2.0 & 0.5 & 0.0 & 0.8 \\
\hline Globobulimina sp. & 0.0 & 0.0 & 0.4 & 1.6 & 0.0 & 2.0 & 0.0 & 1.8 & 3.2 & 0.0 & 2.8 & 9.9 \\
\hline Praeglobobulimina spinescens & 0.0 & 1.0 & 0.4 & 0.0 & 0.0 & 0.0 & 0.0 & 6.1 & 9.9 & 6.1 & 2.8 & 6.1 \\
\hline Pleurostomella spp. & 0.0 & 0.0 & 0.0 & 0.0 & 0.0 & 0.0 & 0.0 & 0.0 & 1.2 & 2.5 & 0.0 & 2.3 \\
\hline Pullenia quinqueloba & 0.0 & 0.7 & 1.2 & 0.0 & 0.0 & 0.7 & 2.6 & 0.3 & 0.0 & 0.0 & 1.4 & 1.5 \\
\hline P. bulloides & 0.0 & 0.0 & 0.0 & 0.5 & 0.0 & 4.7 & 1.7 & 0.9 & 1.2 & 4.0 & 1.4 & 12.2 \\
\hline Nonion sp. & 0.8 & 0.0 & 0.0 & 0.0 & 2.9 & 5.4 & 0.0 & 0.0 & 0.0 & 0.5 & 0.0 & 0.0 \\
\hline Nonionella sp. & 0.0 & 0.7 & 2.4 & 0.0 & 0.6 & 0.0 & 0.0 & 27.5 & 15.1 & 2.5 & 1.4 & 0.0 \\
\hline Nonionellina sp. & 0.0 & 0.0 & 0.0 & 0.0 & 0.0 & 0.0 & 0.0 & 0.0 & 0.0 & 2.0 & 0.0 & 5.3 \\
\hline Melonis barleeanum & 43.4 & 48.6 & 26.4 & 4.8 & 5.8 & 24.2 & 3.5 & 5.8 & 4.8 & 7.1 & 11.1 & 6.9 \\
\hline Astrononion sp. & 0.0 & 0.3 & 0.0 & 0.0 & 0.0 & 0.0 & 0.0 & 2.4 & 0.0 & 1.5 & 0.0 & 0.0 \\
\hline Gyroidinoides sp. & 0.0 & 0.3 & 0.0 & 4.3 & 5.2 & 6.0 & 0.0 & 1.5 & 0.8 & 1.5 & 6.9 & 3.8 \\
\hline Valvulineria laevigata & 4.1 & 4.5 & 1.2 & 0.0 & 0.0 & 0.0 & 0.0 & 1.5 & 0.0 & 0.5 & 0.0 & 1.5 \\
\hline Sphaeroidina bulloides & 0.0 & 0.0 & 0.0 & 1.1 & 1.7 & 5.4 & 1.7 & 0.0 & 0.0 & 0.0 & 2.8 & 3.8 \\
\hline Hoeglundina elegans & 0.0 & 0.0 & 0.0 & 0.0 & 0.6 & 0.0 & 0.0 & 0.6 & 2.0 & 1.0 & 2.8 & 1.5 \\
\hline Buccella sp. & 5.7 & 0.0 & 0.0 & 0.0 & 0.0 & 0.0 & 0.0 & 0.0 & 0.0 & 0.0 & 0.0 & 0.0 \\
\hline Discorbis sp. & 0.0 & 0.3 & 0.8 & 0.0 & 0.0 & 0.7 & 0.0 & 0.0 & 0.0 & 0.0 & 0.0 & 0.0 \\
\hline Osangularia sp. & 0.0 & 0.0 & 0.0 & 4.3 & 0.0 & 0.0 & 0.0 & 0.3 & 0.0 & 0.0 & 0.0 & 0.8 \\
\hline Cibicides lobatulus & 0.8 & 0.0 & 0.0 & 0.0 & 0.0 & 0.0 & 0.0 & 0.0 & 0.8 & 0.0 & 0.0 & 0.0 \\
\hline Cibicidoides bradyi & 0.0 & 0.7 & 1.2 & 2.1 & 2.3 & 1.3 & 0.0 & 0.3 & 0.8 & 0.0 & 0.0 & 0.0 \\
\hline Cibicidoides sp. 6 & 0.0 & 0.0 & 2.8 & 0.0 & 0.0 & 0.0 & 0.0 & 0.0 & 1.6 & 0.0 & 0.0 & 0.0 \\
\hline C. incrassatus & 0.0 & 0.0 & 0.0 & 0.0 & 0.0 & 0.0 & 0.0 & 0.0 & 0.0 & 0.0 & 0.0 & 8.4 \\
\hline C. pachyderma & 0.0 & 0.0 & 0.0 & 0.5 & 1.2 & 1.3 & 0.0 & 0.0 & 0.0 & 0.5 & 13.9 & 5.3 \\
\hline C. mundulus & 0.0 & 0.0 & 0.0 & 0.0 & 0.0 & 0.0 & 0.0 & 0.6 & 0.4 & 1.0 & 9.7 & 0.0 \\
\hline Planulina wuellerstorfi & 0.0 & 0.0 & 3.7 & 0.0 & 0.6 & 1.3 & 0.0 & 0.0 & 0.0 & 0.0 & 0.0 & 0.0 \\
\hline P. rugosa & 0.0 & 0.0 & 0.0 & 0.0 & 0.0 & 0.0 & 0.0 & 0.0 & 0.0 & 0.0 & 2.8 & 1.5 \\
\hline Anomalinoides spissiformis & 0.0 & 0.0 & 0.0 & 0.0 & 0.0 & 0.0 & 0.9 & 0.0 & 0.8 & 0.5 & 0.0 & 4.6 \\
\hline A. globulosus & 0.0 & 0.0 & 0.0 & 0.0 & 0.0 & 1.3 & 0.0 & 0.0 & 0.0 & 1.5 & 0.0 & 0.0 \\
\hline Globocassidulina subglobosa & 0.0 & 0.0 & 0.0 & 2.7 & 2.9 & 0.0 & 0.9 & 4.0 & 3.6 & 3.5 & 0.0 & 0.8 \\
\hline Cassidulina crassa & 0.0 & 0.3 & 0.0 & 0.0 & 0.0 & 14.8 & 0.9 & 0.0 & 1.2 & 0.5 & 1.4 & 1.5 \\
\hline C. reflexa & 0.0 & 0.0 & 0.0 & 38.8 & 32.0 & 14.1 & 0.9 & 0.0 & 0.0 & 0.0 & 0.0 & 0.0 \\
\hline Islandiella laevigata & 29.1 & 25.0 & 16.3 & 0.0 & 0.0 & 0.0 & 0.0 & 0.0 & 0.0 & 0.0 & 0.0 & 0.0 \\
\hline Oridorsalis spp. & 0.0 & 0.0 & 19.1 & 5.3 & 0.0 & 0.0 & 0.0 & 1.5 & 0.8 & 2.0 & 0.0 & 0.8 \\
\hline Cibicidoides sp. G & 0.0 & 0.0 & 0.0 & 6.4 & 5.2 & 0.0 & 0.0 & 0.0 & 2.0 & 0.0 & 0.0 & 0.0 \\
\hline Ehrenbergina sp. & 0.0 & 0.0 & 0.0 & 0.5 & 0.6 & 0.0 & 0.0 & 0.6 & 0.0 & 0.0 & 0.0 & 0.0 \\
\hline
\end{tabular}

dence of reworking and downslope contamination. Samples from the upper Miocene of Site 613 contained insufficient foraminifers for quantitative study.

The samples were soaked in a hydrogen peroxide $(3 \%)$ solution and washed through a $63-\mu \mathrm{m}$ sieve with a sodium hexametaphosphate solution. Aliquots from the $>150-\mu \mathrm{m}$ size fraction were picked and mounted on a reference slide. Three hundred specimens were picked when possible. The census data are presented as percentages of the total benthic foraminifers counted (Tables 1, 2).

The use of the $>150-\mu \mathrm{m}$ size fraction for quantitative deep-sea benthic foraminiferal study is arbitrary. Scott (this volume) and Poag and Low (this volume) examined the $>63-\mu \mathrm{m}$ sieve fraction for benthic foraminifers; Lohmann (1978) and Miller and Lohmann (1982) examined the $>250-\mu \mathrm{m}$ size fraction, while Phleger et al. (1953), Streeter (1973), and Streeter and Lavery (1982) examined the $>150$ $\mu \mathrm{m}$ size fraction. Schnitker $(1974,1979)$ used the $>125-\mu \mathrm{m}$ size fraction. We routinely use the $>150-\mu \mathrm{m}$ size fraction because this avoids problems involved in identifying small specimens and it is faster to pick. Although the abundances of some very small taxa are underestimated (e.g., Epistominella spp., cf. Streeter, 1973 and Schnitker, 1974; Bolivina spp., cf. Miller et al., 1984, and Poag et al., 1984), many faunal patterns are observable in coarser size fractions. For example, the widespread dominance of Uvigerina peregrina in slope sediments has been observed in the $>250-\mu \mathrm{m}$ fraction (Miller and Lohmann, 1982), the $>150-\mu \mathrm{m}$ fraction (Streeter and Lavery, 1982), the $>125-\mu \mathrm{m}$ fraction (Schnitker, 1979), and the $>63-\mu \mathrm{m}$ fraction (Scott, this volume). 
Table 2. Benthic foraminiferal census data, Site 613.

\begin{tabular}{|c|c|c|c|c|c|c|}
\hline $\begin{array}{l}\text { Core-Section } \\
\text { Sub-bottom depth (m) } \\
\text { Number counted }\end{array}$ & $\begin{array}{l}13, \mathrm{CC} \\
211.6 \\
123.0\end{array}$ & $\begin{array}{l}14, C C \\
221.3 \\
256.0\end{array}$ & $\begin{array}{l}15, \mathrm{CC} \\
230.7 \\
281.0\end{array}$ & $\begin{array}{l}16, C C \\
240.3 \\
122.0\end{array}$ & $\begin{array}{l}17, \mathrm{CC} \\
244.3 \\
177.0\end{array}$ & $\begin{array}{l}18, \mathrm{CC} \\
258.6 \\
212.0\end{array}$ \\
\hline Sigmoilopsis schlumbergeri & 1.6 & 1.6 & 0.7 & 0.0 & 3.4 & 6.1 \\
\hline Vulvulina spinosa & 0.0 & 0.0 & 0.0 & 0.0 & 0.0 & 0.0 \\
\hline Martinotiella sp. & 0.0 & 0.0 & 0.0 & 0.0 & 0.0 & 0.0 \\
\hline Dentalina spp. & 0.0 & 0.0 & 0.4 & 0.0 & 1.1 & 0.9 \\
\hline Fursenkoina mexicana & 0.0 & 0.0 & 0.0 & 0.0 & 0.0 & 0.0 \\
\hline Chilostomellina sp. & 0.0 & 0.0 & 0.0 & 0.0 & 0.0 & 0.0 \\
\hline Karneriella subglabra & 1.6 & 0.8 & 0.0 & 0.0 & 0.0 & 0.0 \\
\hline Eggerella bradyi & 4.1 & 0.8 & 0.0 & 0.0 & 1.7 & 0.0 \\
\hline Stilostomella aculeata & 0.0 & 0.0 & 0.0 & 0.0 & 0.0 & 0.0 \\
\hline S. curvatura & 0.0 & 0.0 & 0.0 & 0.0 & 0.0 & 0.0 \\
\hline S. lepidula & 12.2 & 0.0 & 0.0 & 0.0 & 0.0 & 0.0 \\
\hline Bolivina alata & 0.0 & 0.0 & 0.0 & 0.0 & 0.0 & 0.0 \\
\hline Plectofrondicularia sp. & 4.9 & 1.6 & 0.0 & 11.5 & 4.5 & 3.8 \\
\hline Trifarina sp. & 0.8 & 0.0 & 0.0 & 0.0 & 0.0 & 0.0 \\
\hline Uvigerina probiscidea & 0.0 & 0.0 & 3.6 & 1.6 & 2.3 & 0.0 \\
\hline U. hispida & 0.8 & 22.7 & 6.0 & 0.0 & 1.7 & 5.2 \\
\hline$U$. peregrina & 0.0 & 44.9 & 54.1 & 10.7 & 5.6 & 2.4 \\
\hline$U$. mediterranea & 0.0 & 0.0 & 0.0 & 0.0 & 0.0 & 0.0 \\
\hline U. gallowayi & 0.0 & 0.0 & 0.0 & 0.0 & 0.0 & 0.0 \\
\hline Bulimina striata mexicana & 0.0 & 0.0 & 0.0 & 0.0 & 0.0 & 0.0 \\
\hline B. marginata & 0.0 & 0.0 & 0.0 & 0.0 & 0.0 & 0.0 \\
\hline B. aculeata & 0.0 & 0.0 & 0.0 & 0.0 & 0.0 & 0.0 \\
\hline B. gibba & 0.0 & 0.0 & 0.0 & 0.0 & 0.0 & 0.0 \\
\hline B. alazanensis & 0.0 & 0.0 & 0.4 & 0.0 & 7.9 & 2.4 \\
\hline Buliminella elongata & 0.0 & 0.0 & 0.0 & 0.0 & 0.0 & 0.0 \\
\hline Globobulimina sp. & 0.0 & 0.0 & 0.0 & 0.0 & 0.0 & 0.0 \\
\hline Praeglobobulimina spinescens & 0.0 & 0.4 & 0.0 & 0.0 & 0.0 & 0.0 \\
\hline Pleurostomella spp. & 0.8 & 0.0 & 0.0 & 0.0 & 2.3 & 0.9 \\
\hline Pullenia quinqueloba & 0.0 & 0.0 & 0.0 & 0.0 & 0.0 & 0.0 \\
\hline P. bulloides & 10.6 & 7.8 & 3.2 & 9.0 & 0.0 & 4.7 \\
\hline Nonion sp. & 0.0 & 0.0 & 0.0 & 0.0 & 0.0 & 0.0 \\
\hline Nonionella sp. & 0.0 & 0.0 & 0.0 & 0.0 & 0.0 & 0.0 \\
\hline Nonionellina sp. & 0.0 & 0.0 & 0.0 & 0.0 & 0.0 & 0.0 \\
\hline Melonis barleeanum & 10.6 & 2.0 & 0.7 & 0.8 & 0.0 & 0.5 \\
\hline Astrononion sp. & 0.0 & 0.0 & 0.0 & 0.0 & 0.0 & 0.0 \\
\hline Gyroidinoides sp. & 6.5 & 1.6 & 1.1 & 4.9 & 7.9 & 5.2 \\
\hline Valvulineria laevigata & 0.0 & 0.0 & 0.0 & 0.0 & 0.0 & 0.0 \\
\hline Sphaeroidina bulloides & 0.0 & 2.3 & 0.0 & 0.0 & 0.6 & 0.0 \\
\hline Hoeglundina elegans & 2.4 & 0.0 & 0.7 & 0.0 & 0.0 & 0.0 \\
\hline Buccella sp. & 0.0 & 0.0 & 0.0 & 0.0 & 0.0 & 0.0 \\
\hline Discorbis sp. & 0.0 & 0.0 & 0.0 & 0.0 & 0.0 & 0.0 \\
\hline Osangularia sp. & 0.0 & 0.0 & 0.0 & 0.0 & 0.0 & 0.0 \\
\hline Cibicides lobatulus & 0.0 & 0.0 & 0.0 & 0.0 & 0.0 & 0.0 \\
\hline Cibicidoides bradyi & 5.7 & 0.0 & 0.4 & 0.0 & 3.4 & 2.8 \\
\hline Cibicidoides sp. 6 & 0.0 & 0.0 & 0.4 & 0.0 & 0.0 & 0.0 \\
\hline C. incrassatus & 0.0 & 0.0 & 0.0 & 0.0 & 0.0 & 0.0 \\
\hline C. pachyderma & 8.1 & 0.4 & 0.4 & 0.0 & 0.0 & 0.9 \\
\hline C. mundulus & 0.8 & 0.4 & 0.4 & 3.3 & 5.1 & 2.4 \\
\hline Planulina wuellerstorfi & 3.3 & 0.8 & 0.4 & 16.4 & 0.6 & 0.9 \\
\hline P. rugasa & 0.0 & 0.0 & 0.0 & 0.0 & 0.0 & 0.0 \\
\hline Anomalinoides spissiformis & 0.0 & 0.0 & 0.0 & 0.0 & 0.0 & 0.0 \\
\hline A. globulosus & 0.0 & 0.0 & 0.0 & 0.0 & 0.6 & 0.0 \\
\hline Globocassidulina subglobosa & 22.8 & 9.8 & 26.3 & 36.1 & 48.6 & 54.2 \\
\hline Cassidulina crassa & 0.0 & 0.0 & 0.0 & 0.0 & 0.0 & 0.0 \\
\hline C. reflexa & 0.0 & 0.0 & 0.0 & 0.0 & 0.0 & 0.0 \\
\hline Islandiella laevigata & 0.0 & 0.4 & 0.0 & 0.0 & 0.0 & 0.0 \\
\hline Oridorsalis spp. & 2.4 & 2.0 & 1.1 & 5.7 & 2.3 & 6.6 \\
\hline Cibicidoides sp. G & 0.0 & 0.0 & 0.0 & 0.0 & 0.6 & 0.0 \\
\hline Ehrenbergina sp. & 0.0 & 0.0 & 0.0 & 0.0 & 0.0 & 0.0 \\
\hline
\end{tabular}

Table 3. Neogene relative abundances of Uvigerina spp., Site 613.

\begin{tabular}{lcccc}
\hline $\begin{array}{c}\text { Core-Section } \\
\text { (interval in cm) }\end{array}$ & $\begin{array}{c}\text { Sub-bottom } \\
\text { depth } \\
(\mathrm{m})\end{array}$ & $\begin{array}{c}\text { Number } \\
\text { counted }\end{array}$ & $\begin{array}{c}\text { Uvigerina } \text { spp. } \\
(\%)\end{array}$ & $\begin{array}{c}\text { U. peregrina } \\
(\%)\end{array}$ \\
\hline $13, \mathrm{CC}$ & 211.60 & 174 & 0.6 & 0.0 \\
$14-4,60-64$ & 217.10 & 237 & 34.2 & 33.8 \\
$14, \mathrm{CC}$ & 221.30 & 320 & 56.9 & 35.9 \\
$15-2,60-64$ & 223.60 & 79 & 35.4 & 10.1 \\
$15-4,60-64$ & 226.60 & 514 & 79.2 & 66.7 \\
$15-6,60-64$ & 229.60 & 126 & 60.3 & 39.7 \\
$15, \mathrm{CC}$ & 230.70 & 321 & 60.1 & 51.4 \\
$16-1,60-64$ & 231.60 & 126 & 0.8 & 0.8 \\
$16-2,60-64$ & 233.10 & 63 & 17.5 & 6.3 \\
$16, \mathrm{CC}$ & 240.30 & 177 & 10.2 & 7.3 \\
$17, \mathrm{CC}$ & 244.30 & 268 & 18.7 & 16.0 \\
$18, \mathrm{CC}$ & 258.60 & 315 & 8.0 & 1.6 \\
\hline
\end{tabular}

\section{Site 612}

The Pliocene/Pleistocene boundary has been placed within Core 5 at Site 612 (Site 612 chapter; Poag and Low, this volume). However, Scott (this volume) placed the boundary below Core 8 at Site 612 on the basis of the presence of the benthic foraminiferal species Elphidium excavatum and Fursenkoina fusiformis, which he interpreted as in situ Pleistocene taxa. Based upon the presence of reworked Tertiary and Cretaceous microfossils and glauconite in his samples, Scott suggested that the shipboard placement of the boundary was erroneous. In contrast, we found only a few shallow-water specimens in Cores 7 and 8 and little evidence of reworked older material. Furthermore, Globorotalia tosaensis (zonal criterion base Zone N21, upper Pliocene) first appeared between Samples 612-7,CC and 612-8,CC, whereas the Pleistocene marker G. truncatulinoides first appeared between Samples 612-4,CC and 612-5,CC, consistent with the nannofossil biostratigraphy. We therefore agree with the site chapter and Poag and Low (this volume), and place the upper Pleistocene/upper Pliocene contact at the unconformity noted in Core 5, Section 3 .

Benthic foraminiferal first and last occurrences are scattered throughout the studied section, with two exceptions (Fig. 1; Table 1):

1. Several last occurrences are found in Core 13 (Fig. 1). These last occurrences are associated with an unconformity that separates upper upper Miocene (Messinian) from lower upper Miocene (Tortonian) strata (Poag and Low, this volume).

2. The greatest number of disappearances (10) occurs in Core 11 just above the Miocene/Pliocene boundary (Fig. 1), which is recognized by the first occurrences of Ceratolithus acutus (Valentine, this volume) and Globorotalia cf. margaritae (Site 612 chapter) in Sample $612-11, \mathrm{CC}$. The boundary as drawn here (Core 11) is above where the first pinhole apertures were noted in Sphaeroidinella in Sample 612-13,CC (Site 612 chapter).

With the exception of Buliminella elongata, all of the taxa that exhibit last occurrences in this section at Site 612 are known to range into the Holocene elsewhere. Poag (1984) reported that $B$. elongata last occurs in the upper Pliocene of the U.S. Atlantic continental shelf, although at Site 612 it last occurs in the Miocene.

There is an upsection progression of species dominance at Site 612. Bolivina alata and Nonionella sp. have highest relative abundances below the upper Miocene unconformity (Fig. 2). Bulimina alazanensis occurs in high abundance in the uppermost Miocene, and is virtually absent from other portions of the section. Cassidulina reflexa becomes dominant in the lower Pliocene, followed in the upper Pliocene by Melonis barleeanum and Islandiella laevigata.

With the exception of large lenticulinids (Lenticulina ?americana) noted in Sample 612-5,CC there is no significant faunal evidence for reworking of older material or contamination by shallow-water species in the $>150$ $\mu \mathrm{m}$ size fraction from the Neogene section at Site 612 . Widespread contamination might be expected (see Dis- 


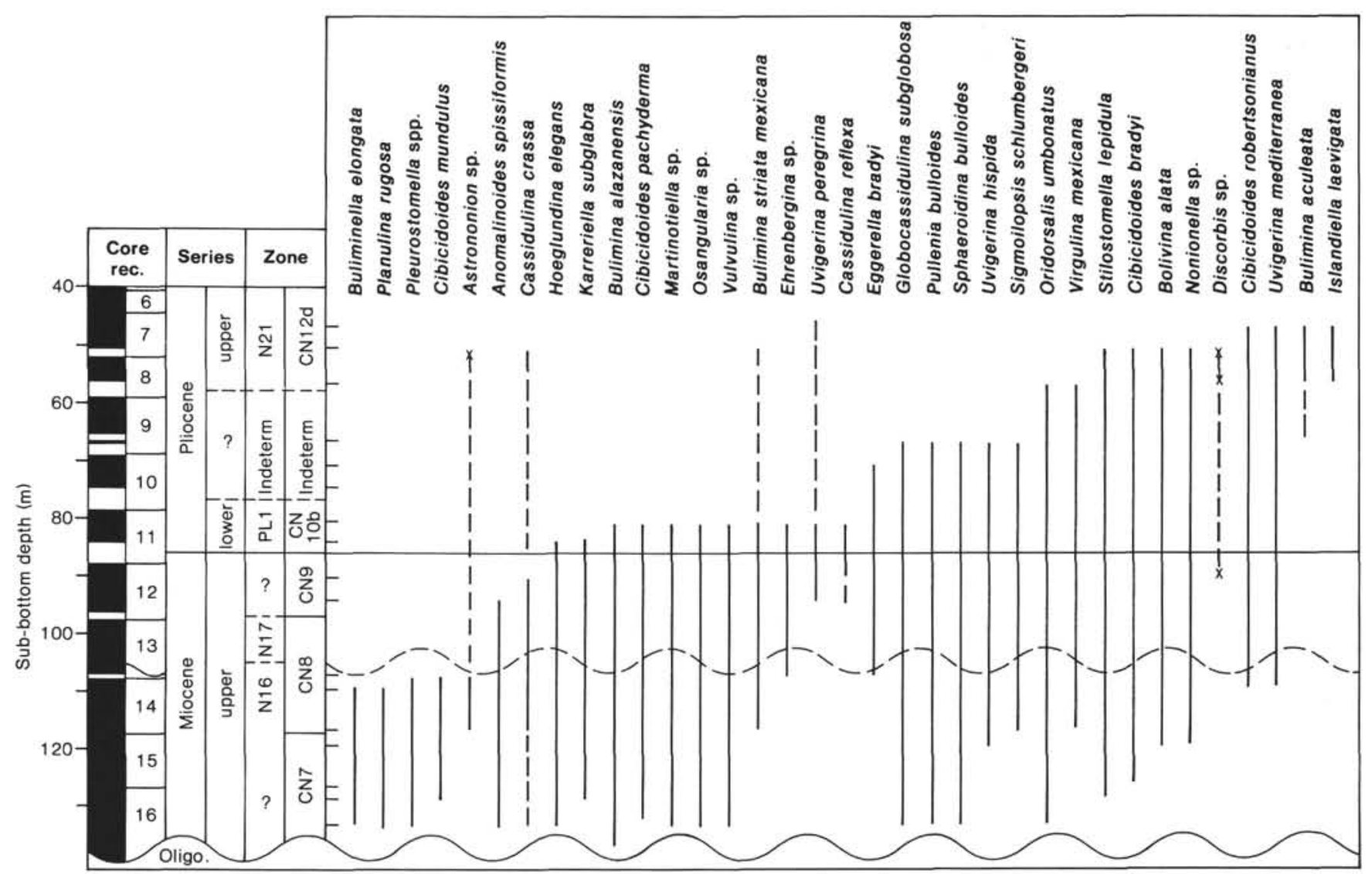

Figure 1. Range chart of Miocene-Pliocene benthic foraminifers at Site 612. Tick marks indicate levels examined for benthic foraminifers. Dashed lines mean uncertain range; $x=$ isolated occurrence.

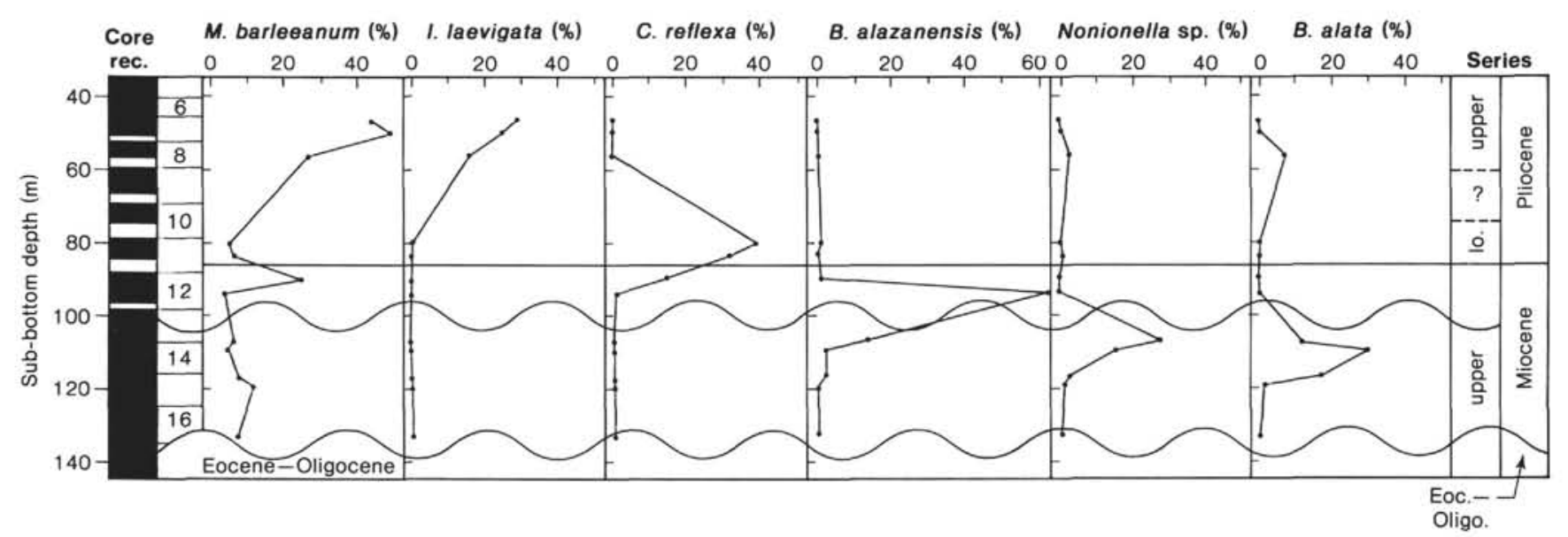

Figure 2. Abundances (\%) of dominant taxa at Site 612.

cussion) considering that the Neogene section is a channel-fill deposit (Poag and Mountain, this volume; G. Mountain, pers. comm., 1985) and visual evidence indicates allocthonous material in Core 13 (chert pebbles, shell fragments, a $3-\mathrm{cm}$ bone fragment; Site 612 chapter). However, the only evidence for reworking and contamination at Site 612 in the $>150-\mu \mathrm{m}$ size fraction is (1) several reworked specimens in Sample 612-7,CC (upper Pliocene, Lenticulina sp. and Globobulimina sp.); (2) a solitary specimen of shallow-water Hanzawaia cf. concentrica in Sample 612-8,CC (upper Pliocene); and (3) a solitary specimen of a shallow-water Eponides sp. in Sample 612-14-2, 60-64 cm (lower upper Miocene).

\section{Site 613}

The Miocene/Pliocene boundary has been placed within Core 19 at Site 613 (Site 613 chapter). There is evidence for limited faunal reworking and downslope contamination in Cores 17, 18, and 19 (Miocene-lower Pliocene). Sample 613-19,CC (upper Miocene) contains one 
specimen of Hanzawaia ammophila, a common form in the Eocene of Sites 612 and 613 (Miller and Katz, this volume) which ranges into the early Miocene elsewhere. This specimen is either reworked or a laboratory contaminant. Reworked Eocene nannofossils were reported from Sample 613-19,CC (Site 613 chapter), although no Eocene planktonic foraminifers were found. Otherwise, there is no evidence for contamination of this sample. Benthic foraminifers are sparse in Sample 613-19,CC, but apparently represent an in situ late Neogene fauna (Uvigerina hispida, Bulimina alazanensis). Section 61319-3 (upper Miocene) contains a very sparse fauna consisting of predominantly reworked specimens including Eocene-Oligocene planktonic foraminifers (Subbotina linaperta and $S$. cf. S. sellii). Most benthic taxa in Sample 613-18,CC (lower Pliocene) are interpreted as in situ, although a few shallow-water specimens were noted, including Buccella sp., Hanzawaia cf. $H$. concentrica, and Eponides sp. Reworked Eocene radiolarians were also identified in this sample (Site 613 chapter). Several specimens of a shallow-water Hanzawaia cf. H. concentrica were identified in Sample 613-17,CC (lower Pliocene). Sections 613-13-5 to 613-13-1 (upper Pliocene) contained some reworked Eocene radiolarians (Site 613 chapter). The remainder of the Pliocene section at Site 613 showed no evidence of reworking or contamination in the $>150$ $\mu \mathrm{m}$ size fraction. The Pliocene/Pleistocene boundary has been placed within Core 11 (Site 613 chapter). Samples from Core 12 contain very sparse faunas and are not included in this study.

Nearly all of the taxa that show last occurrences in the Pliocene section at Site 613 are known to range into the Recent (Fig. 3). The only first occurrence that appears to be stratigraphically significant is Islandiella laevigata in Zone PL2. Islandiella laevigata first appeared in Site 612 in Zone N21. Continuously ranging taxa and infrequently occurring taxa are listed in Table 2 and in the Appendix.

Quantitative studies (Fig. 4) show that Globocassidulina subglobosa dominates the benthic fauna in the lower Pliocene at Site 613. This biofacies is replaced in the "middle" Pliocene by a Uvigerina biofacies, including $U$. peregrina and $U$. hispida. There is a suggestion in our uppermost sample that $G$. subglobosa regains species dominance in the upper Pliocene.

\section{Sites 612 and 613 Compared with Site 604}

Examination of six samples from lower upper Miocene (Zones CN7-CN8 = NN9-NN10) at Hole 604 (Wise et al., in press) shows considerable evidence of downslope transport of Miocene and reworking of Eocene foraminifers. This is not surprising, considering the fact that the sediments examined consist of debris flow deposits in the thalweg of a buried channel system. In contrast, Site 613 was drilled in an interchannel area and slightly upslope from Site 604, where the upper Miocene section is considerably thinner and shows much less benthic foraminiferal evidence for transport and reworking.

Sample 604-30-1, 38-40 cm consists of an Eocene clast in a upper Miocene matrix (Zone CN7 = NN9; Wise et al., in press). Foraminifers indicate that this clast is of middle Eocene age, containing a benthic and planktonic fauna similar to that found at nearby Site 613 (Truncorotaloides rohri, Acarinina bullbrooki, A. pentacamera-

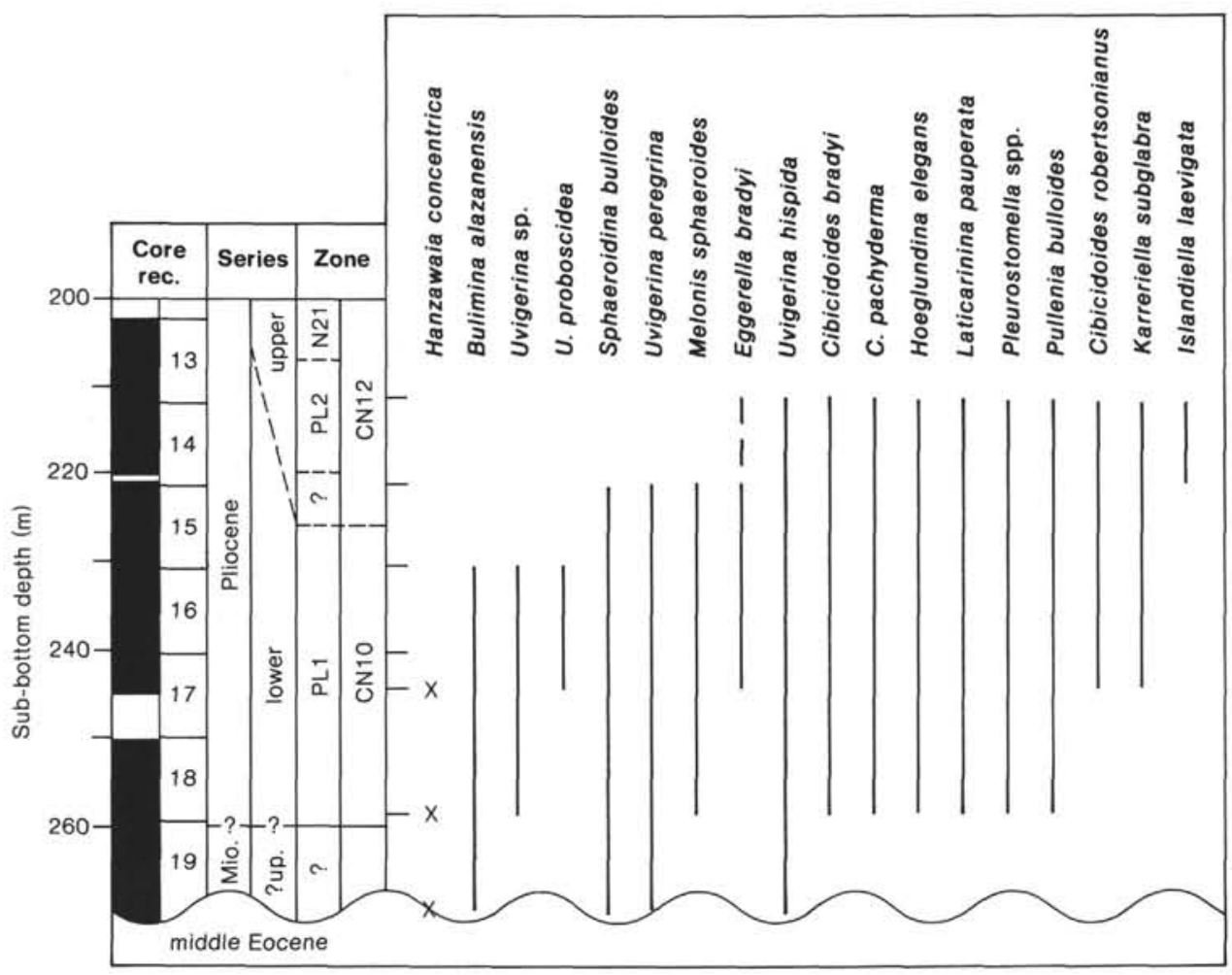

Figure 3. Range chart of Miocene-Pliocene benthic foraminifers at Site 613. 


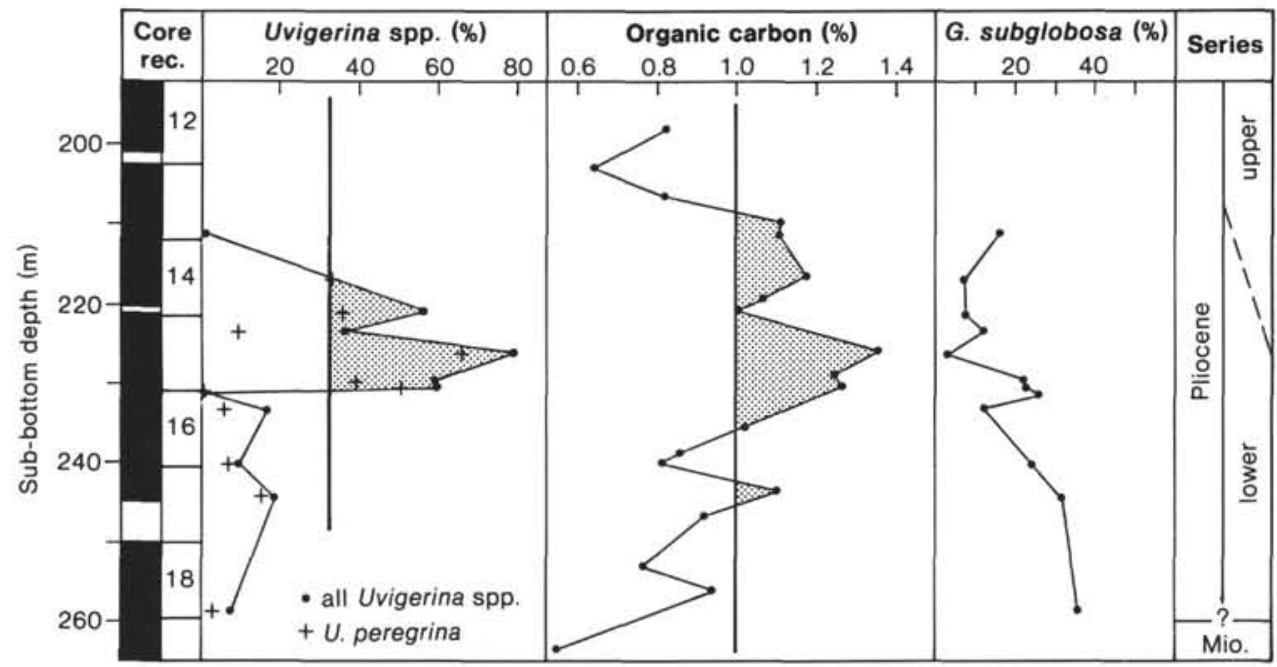

Figure 4. Abundances (\%) of dominant taxa and sedimentary organic carbon at Site 613.

ta, A. aragonensis, Bulimina trinitatensis, Cibicidoides subspiratus, and C. tuxpamensis), suggesting that the slump blocks were not transported a great distance downslope.

Samples from Cores $604-26$ and 27 contain a middle to late Miocene planktonic foraminiferal fauna with reworked Eocene foraminifers: (1) Samples 604-27-1, 102$104 \mathrm{~cm}$ and 604-27-1, 114-115 cm, Eocene: Truncorotaloides rohri, Catapsydrax unicavus; Miocene: Globigerinoides sacculifera; (2) Sample 604-27-1, 23-25 cm, Eocene: Acarinina sp.; Miocene: Globigerinoides trilobus, Globoquadrina dehiscens; Sample 604-26-3, 52-54 cm, Eocene: T. rohri; Miocene: Neogloboquadrina continuosa, Globorotalia menardii, Orbulina sp.

In addition to reworking of Eocene foraminifers, there is evidence of significant downslope transport at Site 604 . The benthic fauna of Sample 604-26-3, 52-54 cm contains abundant diverse shallow-water neritic elements (Cibicides spp. and Hanzawaia cf. H. concentrica), and a fauna which may be of deeper water origin (including Sphaeroidina bulloides, Cibicidoides pachyderma, and Melonis barleeanum). Sample 604-27-1, 23-25 cm contains a fauna similar to that described from the Miocene of upslope Site 612: Cassidulina reflexa, Bolivina alata, Bulimina alazanensis, and Nonionellina sp. It is possible that the fauna was transported from the vicinity of Site 612 to Hole 604; however, lack of comparative Miocene material at Site 613 prevents determination of the nature of in situ fauna in the vicinity of Hole 604 .

These mixtures of in situ, reworked, and transported fauna from the upper Miocene at Site 604 contrast with the primarily in situ record from the Pliocene of Site 613 and the Miocene-Pliocene of Site 612. The difference in transported material among the three sites can best be explained by their geologic settings. Hole 604 lies in the channel thalweg, penetrates basal Tortonian strata, and contains clasts, reworked foraminifers, and downslope contaminants. Site 613 is located on the nearby interchannel area, penetrated only a thin Messinian section, and has little evidence of reworking or contamination. Site 612 is located updip slightly off of the thalweg of a basal Tortonian canyon and contains little evidence of reworking or contamination.

\section{DISCUSSION}

Benthic foraminifers identified in the Miocene-Pliocene sections of Sites 612 and 613 are distinct from coeval biofacies of the U.S. Atlantic emergent coastal plain (Miocene Pungo River and Pliocene Yorktown Formations; Gibson, 1967; Schnitker, 1970) or submergent coastal plain (continental shelf ASP, AMCOR, COST boreholes; Poag, 1984; Melillo, 1985). Typical Neogene coastal plain biofacies consist of neritic taxa including: Bolivina paula, Buliminella elongata, Buliminella elegantissima, Cassidulina crassa, Islandiella laevigata, Elphidium sp., Epistominella pontoni, Florilus pizzarensis, Hanzawaia concentrica, Nonionella sp., and Trifarina angulosa (Gibson, 1967; Poag, 1984). This biofacies also has been noted from upper Oligocene strata in this region (Olsson et al., 1980) and in southwest France (Butt, 1966). A shallower, lower diversity inner neritic biofacies has been reported from upper levels of the Yorktown Formation consisting of dominant Elphidium spp., Buccella spp., Rosalina sp., and Nonionella sp. (Gibson, 1967; Schnitker, 1970). In contrast, the benthic foraminiferal assemblages at Sites 612 and 613 contain mostly known middle bathyal-abyssal taxa: Anomalinoides globulosus, Bulimina aculeata, B. alazanensis, Cibicidoides bradyi, $C$. mundulus (= kullenbergi), Eggerella bradyi, Ehrenbergina sp., Globobulimina sp., Globocassidulina subglobosa, Hoeglundina elegans, Melonis barleeanum, Oridorsalis sp., Planulina wuellerstorfi, Pullenia quinqueloba, P. bulloides, Sigmoilopsis schlumbergeri, Karreriella subglabra (= bradyi), Sphaeroidina bulloides, Uvigerina peregrina s.s., and Uvigerina hispida (see van Morkhoven et al. [in press] for discussion of the bathymetric ranges of these taxa).

It is not clear whether the Neogene foraminifers at Sites 612 and 613 represent entirely in situ biofacies (Site 612 and 613 chapters). The Neogene section at Site 612 was deposited in a canyon cut near the end of the middle Miocene; the Neogene section at Site 613 was depos- 
ited as a basal slope fill on an interchannel area of the continental rise (Poag and Mountain, this volume). Some downslope movement of benthic foraminifers was anticipated because of this geological setting. Scott (this volume) acknowledged that the Pleistocene Elphidium-Cassidulina reniforme fauna at Sites 612 and 613 may be a transported glacial ice-margin fauna. However, he favored an in situ interpretation for these faunas based upon the presence of living (stained) Elphidium sp. on the modern slope (Schafer et al., 1981). We note rare shallow-water elements (Buccella, Discorbis, Eponides) and reworked Eocene taxa in the Miocene-Pliocene sections at Sites 612 and 613 (see above, Tables 1, 2). However, we believe that the major faunal elements are in situ. At Site 613, the Pliocene Uvigerina-Globocassidulina biofacies are consistent with the present lowermost bathyal-uppermost abyssal setting. At Site 612 it is possible that Cassidulina reflexa, Islandiella laevigata, Nonionellina sp., and Bolivina alata represent shallower (upper-middle bathyal) elements transported downslope to this lower bathyal setting. However, we believe that the consistent distributional patterns of these taxa (Fig. 2) argue against extensive downslope transport. Nevertheless, (1) if transported elements episodically filled the Neogene channel, they may have been missed by our limited sampling interval, (2) transported elements may be spatially restricted to the same biofacies (hence undetectable), or (3) transported elements may be confined to the finer than $150-\mu \mathrm{m}$ size fraction (however, Poag and Low [this volume] found little evidence of shallowwater forms in the $>63-\mu \mathrm{m}$ fractions that they examined).

Uvigerina peregrina dominates the $>150-\mu \mathrm{m}$ size fraction of modern continental slope and rise biofacies off New Jersey between about 1000 and $2500 \mathrm{~m}$ (Miller and Lohmann, 1982; Streeter and Lavery, 1982). Lutze (1980) and Miller and Lohmann (1982) noted that U. peregrina correlates with high sedimentary organic carbon content; Miller and Lohmann suggested that Uvigerina peregrina was favored in regions of high organic carbon because of reduced interstitial oxygen and/or lowered oxygen values in overlying water. During the last glacial maximum this taxon was dominant on the lower rise (>3000 m; Ledbetter and Balsam, 1985; Balsam, 1981) and in the deep basin (Streeter and Shackleton, 1979). Prior to Leg 95, it was not clear if Uvigerina was important on the slope and upper rise before the Holocene. Scott (this volume) found that $U$. peregrina was important at Site 612 only in the Recent and in Cores 5-8 (Section 612-5-2 is upper Pleistocene, Site 612 chapter; we argue that Section 612-5-3 to Core 612-8 are upper Pliocene; see above).

We note that Uvigerina peregrina occurred in low abundances $(<2 \%)$ on the slope at Site 612 during the Miocene-Pliocene. This taxon dominated the upper rise biofacies at Site 613 during the "middle" Pliocene, but occurred in low abundances during the rest of the Pliocene (Fig. 4). We used the Pliocene section at Site 613 to test the association of high abundance of Uvigerina with high sedimentary organic carbon. Weight percent organic carbon (Table 4) for Pliocene samples from Site 613 was
Table 4. Neogene organic carbon values, Site 613.

\begin{tabular}{ccccc}
\hline $\begin{array}{c}\text { Core-Section } \\
\text { (interval in cm) }\end{array}$ & $\begin{array}{c}\text { Sub-bottom } \\
\text { depth } \\
\text { (m) }\end{array}$ & $\begin{array}{c}\text { Organic } \\
\text { carbon }^{\mathrm{a}} \\
(\%)\end{array}$ & Mean $^{\mathrm{b}}$ \\
\hline $12-3,60-64$ & 196.20 & 0.85 & 0.80 & 0.83 \\
$12-6,60-64$ & 200.70 & 0.54 & 0.74 & 0.64 \\
$13-2,60-64$ & 204.40 & 0.84 & 0.80 & 0.82 \\
$13-3,60-64$ & 207.40 & 1.01 & 1.21 & 1.11 \\
$13-5,60-64$ & 208.90 & 1.11 & 1.09 & 1.10 \\
$14-2,60-64$ & 214.10 & 1.18 & 1.18 & 1.18 \\
$14-4,60-64$ & 217.10 & 0.97 & 1.16 & 1.07 \\
$14-5,60-64$ & 218.60 & 1.06 & 0.96 & 1.01 \\
$15-2,60-64$ & 223.60 & 1.42 & 1.29 & 1.36 \\
$15-4,60-64$ & 226.60 & 1.32 & 1.18 & 1.25 \\
$15-5,60-64$ & 228.10 & 1.27 & 0.69 & - \\
$16-2,60-64$ & 233.10 & 1.01 & 1.03 & 1.02 \\
$16-4,60-64$ & 236.10 & 0.85 & 0.86 & 0.86 \\
$16-5,60-64$ & 237.60 & 0.80 & 0.81 & 0.81 \\
$17-1,60-64$ & 241.10 & 1.13 & 1.08 & 1.11 \\
$17-3,60-64$ & 244.10 & 0.93 & 0.90 & 0.92 \\
$18-1,60-64$ & 250.60 & 0.82 & 0.70 & 0.76 \\
$18-3,60-64$ & 253.60 & 1.00 & 0.90 & 0.95 \\
$19-1,60-64$ & 260.10 & 0.55 & 0.55 & 0.55 \\
\hline
\end{tabular}

a Organic carbon values measured on LECO Carbon Analyzer at Woods Hole Oceanographic Institution. Data provided by W. B. Curry.

b Mean values plotted on Figure 4 except for Sample 613-15-5, 60-64 cm.

c Value considered unreliable.

analyzed on a LECO Carbon Analyzer at Woods Hole Oceanographic Institution (data provided by W. B. Curry). Comparison of the distribution of Uvigerina with percent organic carbon (Fig. 4) shows that high values of Uvigerina $(>30 \%)$ are associated with high organic carbon values $(>1 \%)$. Highest values of Uvigerina $(60$ $80 \%$ ) are associated with highest (1.2-1.4\%) organic carbon values and a homogenous, clay-rich zone (Cores 14-16) identified by visual observation and on gammaray logs (Site 613 chapter). We suggest that the "middle" Pliocene acme of Uvigerina spp. at Site 613 represents an interval of increased supply of organic carbon, which reduced the oxygen content of interstitial and possibly overlying water.

\section{ACKNOWLEDGMENTS}

We thank A. J. Melillo, G. S. Mountain, C. W. Poag, and G. Lutze for reviews, W. B. Curry (WHOI) for providing analyses of percent organic carbon, D. Scott (Dalhousie) and the shipboard party for data and discussions, S. Hambos for technical assistance, D. Greig (Chevron) for producing the SEM micrographs, and S. W. Wise (Florida State) for providing samples from Site 604 . Samples were provided by the DSDP. This work supported by NSF Contract OCE 8500859 and a consortium of oil companies (Arco, BP, Chevron, Elf, Exxon, Gulf, Mobil, Phillips, Shell, Shell International, Texaco, and Union).

This is LDGO Contribution Number 4047.

\section{REFERENCES}

Balsam, W., 1981. Late Quaternary sedimentation in the western North Atlantic: stratigraphy and paleoceanography. Palaeogeogr., Palaeoclimatol., Palaeoecol., 35:215-240.

Butt, A.A., 1966. Late Oligocene foraminifera from Escornebeou, SW France. Utrecht Micropaleontol. Bull.

Gibson, T. G., 1967. Stratigraphy and paleoenvironment of the Phosphate Miocene strata of North Carolina. Geol. Soc. Am. Bull., 78: 631-649.

Ledbetter, M. T., and Balsam, W. L., 1985. Paleoceanography of the deep western boundary undercurrent on the North American continental margin for the past 25,000 yr. Geology, 13(3):181-184. 
Lohmann, G. P., 1978. Abyssal benthonic foraminifera as hydrographic indicators in the western South Atlantic Ocean. J. Foram. Res., 8: 6-34.

Lutze, G. F., 1980. Depth distribution of benthic foraminifera on the continental margins of N.W. Africa. "Meteor" Forschungsergeb. Reihe C, 32:31-80.

May, J. A, Warme, J. E., and Slater, R. A. 1983. Role of submarine canyons on shelfbreak erosion and sedimentation: modern and ancient examples. Soc. Econ. Paleontol. Mineral. Spec. Publ., 33: 315-332.

Melillo, A. J., 1985. Late Oligocene to Pliocene sea-level cycle events in the Baltimore Canyon Trough and western North Atlantic Basin [Unpubl. thesis]. Rutgers University, New Brunswick, NJ.

Miller, K. G., Curry, W. B., and Ostermann, D. R., 1984. Late Paleogene (Eocene to Oligocene) benthic foraminiferal oceanography of the Goban Spur region, Deep Sea Drilling Project Leg 80. In Graciansky, P. C. de, Poag, C. W., et al., Init. Repts. DSDP, 80: Washington (U.S. Govt. Printing Office), 505-538.

Miller, K. G., and Lohmann, G. P., 1982. Environmental distribution of Recent benthic foraminifera on the northeast U.S. continental slope. Geol. Soc. Am. Bull., 93(3):200-206.

Miller, K. G., Mountain, G. S., and Tucholke, B. E., 1985. Oligocene glacio-eustasy and erosion on the margins of the North Atlantic. Geology, 13:10-13.

Natland, M. L., 1963. Presidential address: paleoecology and turbidites. J. Paleontol., 37(4):946-951.

Olsson, R. K., Miller, K. G., and Ungrady, T. E., 1980. Late Oligocene transgression of middle Atlantic coastal plain. Geology, 8: 549-554.

Phleger, F. B., Parker, F. L., and Peirson, J. F., 1953. North Atlantic Foraminifera. Rep. Swed. Deep-Sea Exped. 1947-1948. 7(1):49.

Poag, C. W., 1984. Neogene stratigraphy of the submerged U.S. Atlantic margin. Palaeogeogr., Palaeoclimatol., Palaeoecol., 47: 103-127.

1985. Cenozoic and Upper Cretaceous sedimentary facies and depositional systems of the New Jersey slope and rise. In Poag, C. W. (Ed.), Geologic Evolution of the United States Atlantic Margin: New York (Van Nostrand Reinhold), pp. 343-365.

Poag, C. W., Reynolds, L. A., Mazzullo, J. M., and Keigwin, L. D. Jr., 1984. Foraminiferal, lithic, and isotopic changes across four major unconformities at Deep Sea Drilling Project Site 548, Goban Spur. In Graciansky, P. C. de, Poag, C. W., et al., Init. Repts. DSDP, 80: Washington (U.S. Govt. Printing Office), 539-556.

Schafer, C. T., Cole, F. E., and Carter, L., 1981. Bathyal zone benthic foraminiferal genera off northeast Newfoundland. J. Foram. Res., 11(4):296-313.

Schnitker, D., 1970. Upper Miocene foraminifera from near Grimesland, Pitt County, North Carolina. N.C. Dep. Conserv. Dev. Spec. Publ., 3:1-128.

1974. Western Atlantic abyssal circulation during the past 120,000 years. Nature, 248:385-387.

1979. Cenozoic deep water foraminifers, Bay of Biscay. In Montadert, L., Roberts, D. G., et al., Init. Repts. DSDP, 48: Washington (U.S. Govt. Printing Office), 377-413.

Stanley, D. J., and Unrug, R., 1972. Submarine channel deposits, fluxoturbidites and other indicators of slope and base-of-slope environments in modern and ancient marine basins. In Rigby, J. K., and Hamblin, W. K. (Eds.), Recognition of Ancient Sedimentary Environments. Soc. Econ. Paleontol. Mineral. Spec. Publ., 16:287-340.

Streeter, S. S., 1973. Bottom water and benthonic foraminifera in the North Atlantic: glacial-interglacial contrasts. Quat. Res., 3:131141.

Streeter, S. S., and Lavery, S. A., 1982. Holocene and latest glacial benthic foraminifera from the slope and rise off eastern North America. Geol. Soc. Am. Bull., 93(3):190-199.

Streeter, S. S., and Shackleton, N. J., 1979. Paleocirculation of the deep North Atlantic: 150,000 year record of benthic foraminifera and oxygen-18. Science, 203:168-171.

van Hinte, J. E., Wise, S. W., et al., in press. Init. Rept. DSDP, 93: Washington (U.S. Govt. Printing Office).

van Morkhoven, F. P. C. M., Berggren, W. A., and Edwards, A. E., in press. Cenozoic cosmopolitan deep-water benthic foraminifera. Elf Aquitaine, Spec. Publ.
Wise, S. W., van Hinte, J. E., Mountain, G. S., Biart, B. N., Covington, J. M., et al., in press. Mesozoic-Cenozoic clastic depositional environments revealed by DSDP Leg 93 drilling on the continental rise off the Eastern United States. In Summerhayes, C. P., Shackleton, N. J. (Eds.), North Atlantic Paleoceanography. Geol. Soc. London, Spec. Publ.

Date of Initial Receipt: 8 July 1985

Date of Acceptance: 30 April 1986

\section{APPENDIX \\ Neogene Benthic Species List}

Inferred In Situ Taxa

Anomalinoides globulosus (Chapman and Parr)

A. spissiformis (Cushman and Stainforth)

Bolivina alata (Seguenza)

Bulimina aculeata (d'Orbigny)

B. alazanensis Cushman

B. gibba Fornasini

B. marginata (d'Orbigny)

B. striata mexicana Cushman

Buliminella elongata (d'Orbigny)

Cassidulina crassa d'Orbigny

C. reflexa Galloway and Wissler

Cibicides lobatulus (Walker and Jacob)

Cibicidoides bradyi (Trauth)

C. incrassatus (Fichtel and Moll)

C. mundulus (Brady, Parker and Jones)

C. pachyderma (Rzehak)

Eggerella bradyi (Cushman)

Fursenkoina mexicana (Cushman)

Globocassidulina subglobosa (Brady)

Hoeglundina elegans (d'Orbigny)

Islandiella laevigata (d'Orbigny)

Karreriella subglabra (Guembel)

Melonis barleeanum (Williamson)

Oridorsalis umbonatus (Reuss)

Planulina rugosa (Phleger and Parker)

P. wuellerstorfi (Schwager)

Praeglobobulimina spinescens (Brady)

Pullenia bulloides (d'Orbigny)

$P$. quinqueloba (Reuss)

Sigmoilopsis schlumbergeri (Silvestri)

Sphaeroidina bulloides d'Orbigny

Stilostomella aculeata (Cushman and Renz)

S. curvatura (Cushman)

S. lepidula (Schwager)

Uvigerina gallowayi Cushman

$U$. hispida Schwager

$U$. mediterranea Hofker

$U$. peregrina (Cushman)

$U$. proboscidea Schwager

Valvulineria laevigata Phleger and Parker

Vulvulina spinosa Cushman

Shallow-Water Taxa Noted in the Miocene-Pliocene at Sites 612 and 613

Lenticulina cf. americana (Cushman)

Hanzawaia concentrica (Cushman)

Reworked Eocene Benthic Taxa Noted in the Miocene at Site 604

B. trinitatensis (Cushman and Jarvis)

C. subspiratus (Nuttall)

C. tuxpamensis (Cole)

Reworked Eocene Taxon Noted in the Miocene at Site 613

Hanzawaia ammophila (Guembel) 


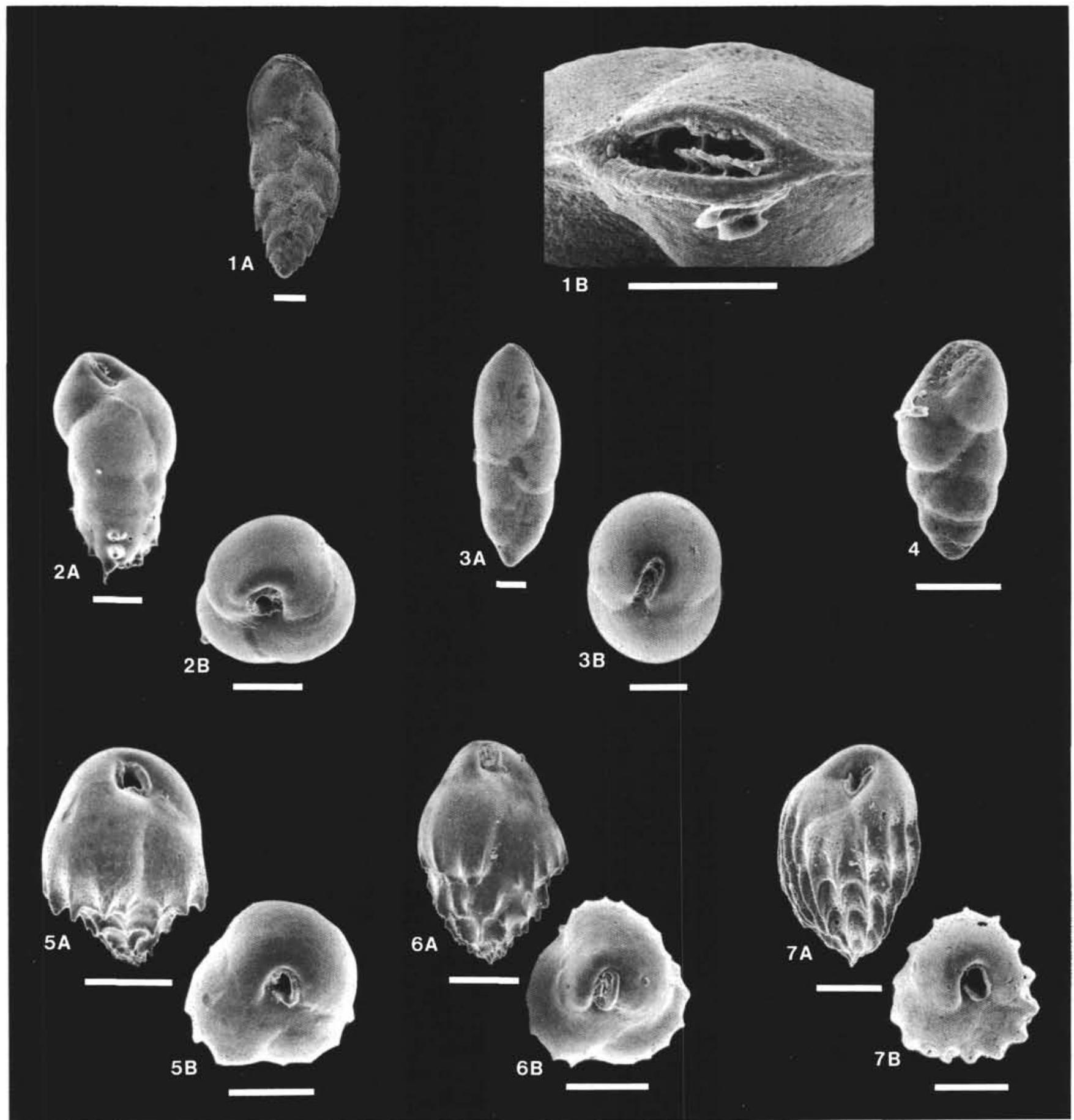

Plate 1. Scale bar $=100 \mu \mathrm{m}$. 1A-B. Bolivina alata. Sample $612-14-2,60-64 \mathrm{~cm}$. 2A-B. Bulimina aculeata. Sample $612-7-2,60-64 \mathrm{~cm}$. 3A-B. Fursenkoina mexicana. Sample 612-8,CC. 4. Buliminella elongata. Sample $612-14-2,60-64 \mathrm{~cm}$. 5A-B. Bulimina marginata. Sample 612-11,CC. 6A-B. Bulimina striata mexicana. Sample 612-11-2, 60-64 cm. 7A-B. Bulimina alazanensis. Sample 612-12-5, 7-9 cm. 


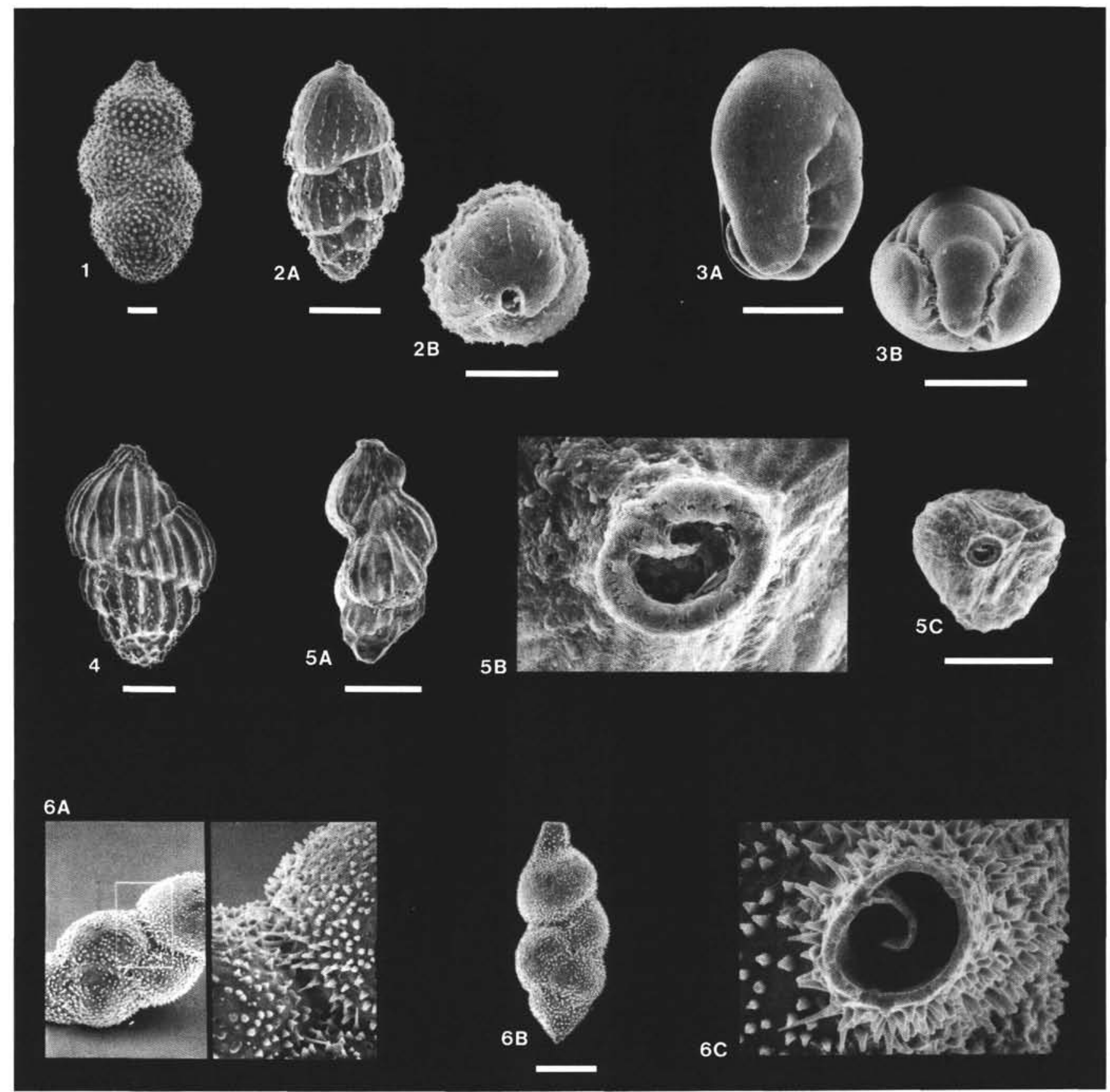

Plate 2. Scale bar $=100 \mu \mathrm{m}$. 1. Uvigerina hispida. Sample 612-11,CC. 2A-B. Uvigerina peregrina. Sample 612-7-2, 60-64 cm. 3A-B. Chilostomellina sp. Sample 612-13,CC. 4. Uvigerina mediterranea. Sample 612-10,CC. 5A-C. Trifarina sp. Sample 612-8,CC. 6A-C. Uvigerina proboscidea. Sample 612-7-2, 60-64 cm. 


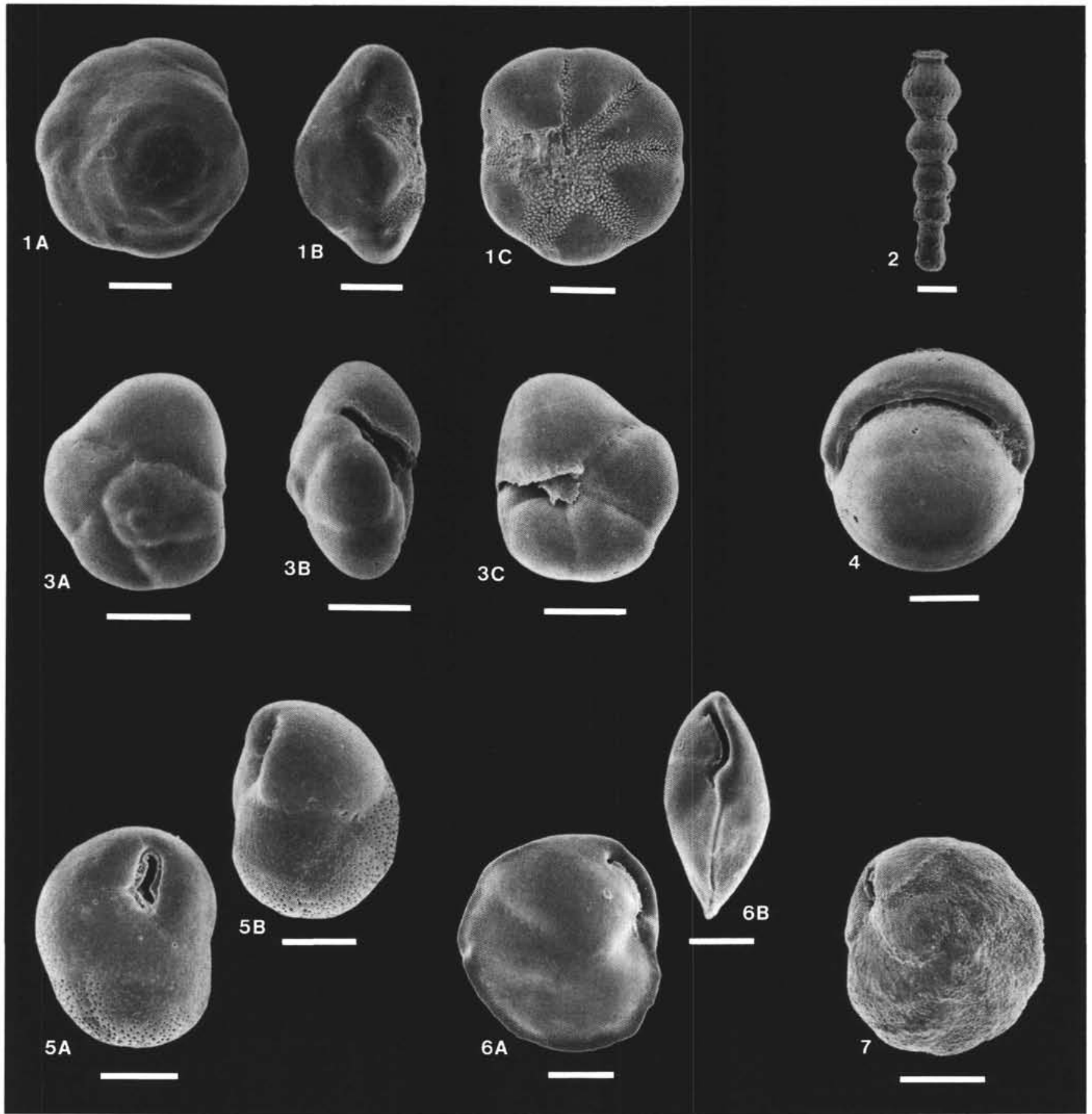

Plate 3. Scale bar $=100 \mu \mathrm{m}$. 1A-C. Buccella sp. Sample 612-7-2, 60-64 cm. 2. Stilostomella lepidula. Sample 612-7,CC. 3A-C. Valvulineria laevigata. Sample 612-7-2, 60-64 cm. 4. Pullenia bulloides. Sample 612-12-2, 60-64 cm. 5A-B. Globocassidulina subglobosa. Sample 61213,CC. 6A-B. Islandiella laevigata. Sample 612-7,CC. 7. Cassidulina reflexa. Sample 612-11-2, 60-64 cm. 


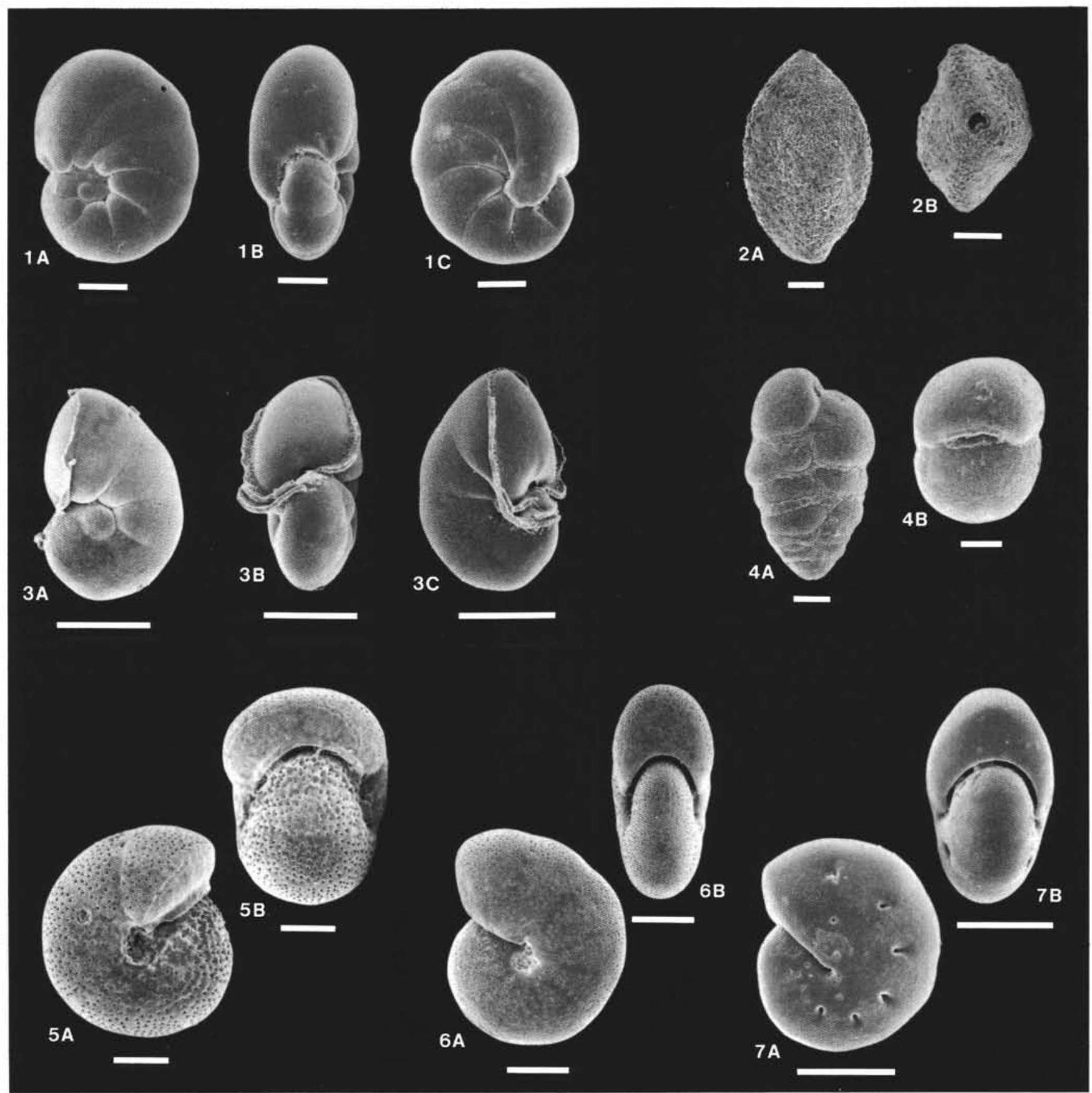

Plate 4. Scale bar $=100 \mu \mathrm{m} . \quad$ 1A-C. Nonionella sp. Sample 612-13,CC. 2A-B. Sigmoilopsis schlumbergeri. Sample 612-14,CC. 3A-C. Nonionellina sp. Sample 612-14,CC. 4A-B. Karreriella subglabra. Sample 612-14,CC. 5A-B. Melonis sphaeroides. Sample 612-14-2, 60-64 cm. 6A-B. Melonis barleeanum. Sample 612-7-2, 60-64 cm. 7A-B. Astrononion sp. Sample 612-13,CC. 


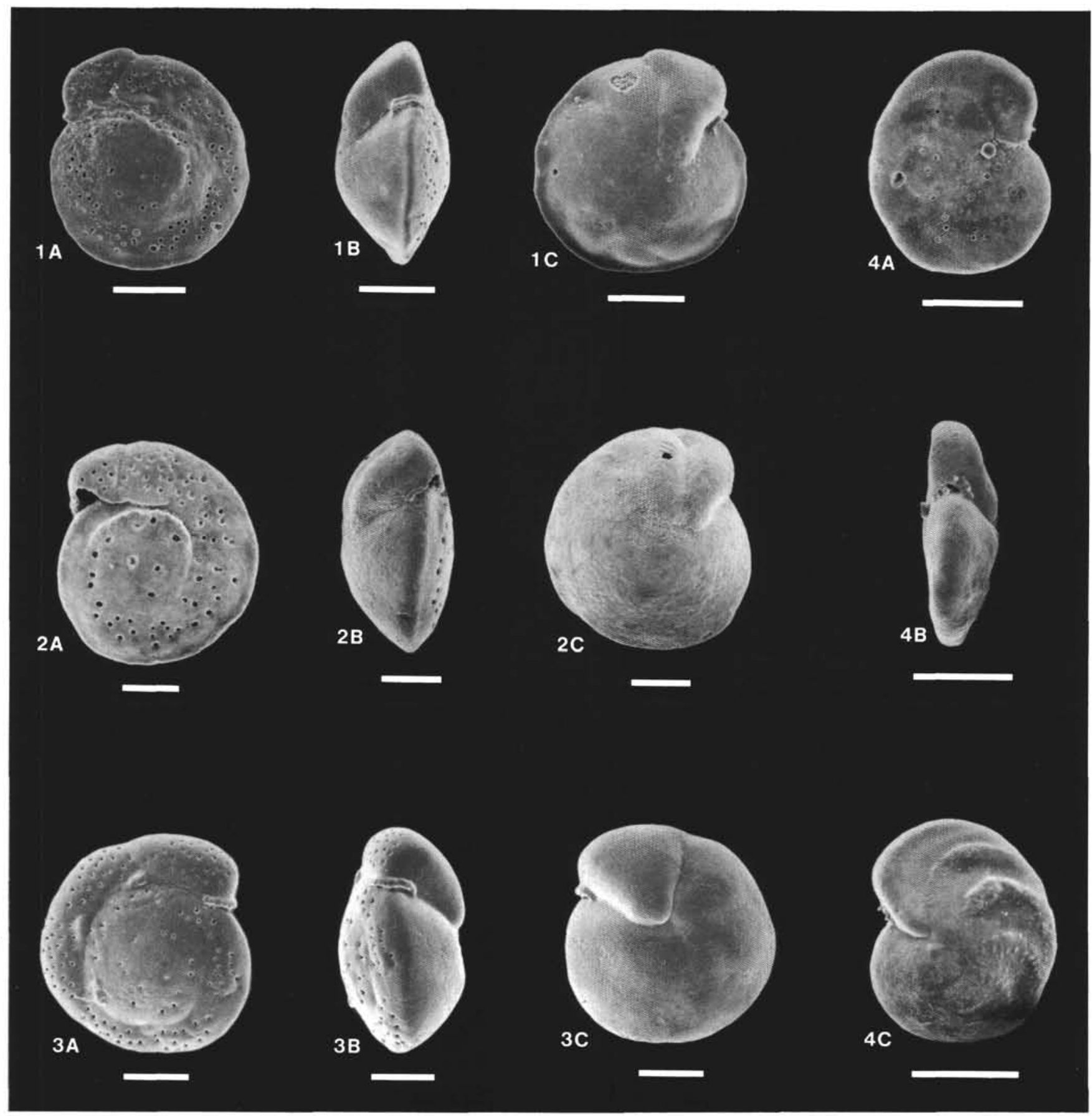

Plate 5. Scale bar $=100 \mu \mathrm{m}$. 1A-C. C. pachyderma. Sample 612-11,CC. 2A-C. Cibicidoides mundulus. Sample 612-13,CC. 3A-C. C. bradyi. Sample 612-11,CC. 4A-C. Planulina wuellerstorfi. Sample 612-11-2, 60-64 cm. 